\title{
Analisis Persepsi Pustakawan terhadap Kinerja Tim Penilai Angka Kredit Jabatan Fungsional Pustakawan Universitas Jenderal Soedirman
}

\author{
Anisa Sri Restanti \\ Perpustakaan Universitas Jenderal Soedirman \\ email: anisasrirestanti@gmail.com
}

\begin{abstract}
Librarians are functional positions recognized by the Indonesian government. Librarians have the freedom to pursue their career paths. The terms of promotion of librarians are determined by cumulative credit point achieved in a given period. The cumulative credit is prepared in the List of Proposals for Determination of Credit Point (DUPAK). The assessment team of the librarian is tasked with assessing the DUPAK to be used for promote the librarian concerned. The performance of the assessment team plays an important role in librarian career development. This study aimed to find out how the librarian's perception of performance the assessment team of the librarian at Jenderal Soedirman University This research is a quantitative research with survey method. The instrument used was a Likert scale questionnaire to obtain primary data and interviews were used to deepen the primary data analysis. The population in this study were all librarians who submitted DUPAK to the assessment team of the librarian at Jenderal Soedirman University. Data analysis in this study uses the mean formula, grandmean, by compiling guidelines for the meaning of the scores obtained. The performance variables in this study are broken down into three sub-variables, namely work, work behavior, and personal matters relating to work. The results of calculating the average score are 83.6 in the good category. Based on these results it can be seen that the librarian perceives the assessment team of the librarian at General Soedirman University perform well.
\end{abstract}

\begin{abstract}
Pustakawan merupakan jabatan fungsional yang diakui oleh pemerintah Indonesia. Pustakawan memiliki keleluasaan dalam menjalani jenjang karirnya. Syarat kenaikan pangkat dan jabatan pustakawan ditentukan oleh sejumlah angka kredit yang dikumpulkan dalam masa tertentu. Angka kredit tersebut disusun dalam Daftar Usulan Penetapan Angka Kredit (DUPAK). Tim penilai bertugas menilai DUPAK dan hasilnya digunakan untuk kenaikan pangkat ataupun jabatan pustakawan yang bersangkutan. Kinerja tim penilai berperan penting dalam pengembangan karir pustakawan. Tujuan penelitian ini untuk mengetahui bagaimana persepsi pustakawan terhadap kinerja tim penilai angka kredit jabatan fungsional pustakawan di Universitas Jenderal Soedirman. Penelitian ini merupakan penelitian kuantitatif dengan metode survey. Instrumen yang digunakan adalah kuesioner skala likert untuk mendapatkan data primer dan wawancara digunakan untuk memperdalam analisis data primer. Populasi dalam penelitian ini adalah seluruh pustakawan yang mengajukan DUPAK kepada tim penilai angka kredit pustakawan Universitas Jenderal Soedirman. Analisis data dalam penelitian ini menggunakan rumus mean dan grandmean, dengan menyusun pedoman pemaknaan terhadap skor yang didapat. Variabel kinerja dalam penelitian ini dipecah menjadi 3 subvaribel yaitu hasil kerja, perilaku kerja, dan pribadi yang berkenaan dengan pekerjaan. Hasil penghitungan skor rata-rata adalah 83,6 termasuk dalam kategori baik. Berdasarkan hasil tersebut dapat diketahui persepsi pustakawan terhadap kinerja tim penilai angka kredit jabatan fungsional pustakawan Universitas Jenderal Soedirman adalah baik.
\end{abstract}

\section{Keyword :}

Librarians Performance

The assessment team

of the librarian

\section{Kata kunci :}

Pustakawan,

Performa Tim penilai

angka pustakawan

\section{A. PEndAhUlUAN}

Pustakawan merupakan jabatan fungsional yang diakui oleh pemerintah Indonesia. Pustakawan memiliki keleluasaan dalam menjalani jenjang karirnya. Syarat kenaikan pangkat dan jabatan pustakawan ditentukan oleh sejumlah angka kredit yang dikumpulkan dalam masa tertentu. Angka kredit tersebut disusun dalam Daftar Usulan Penetapan Angka Kredit (DUPAK). Tim penilai bertugas menilai DUPAK dan hasilnya 
digunakan untuk kenaikan pangkat ataupun jabatan pustakawan yang bersangkutan. Kinerja tim penilai berperan penting dalam pengembangan karir pustakawan. Tujuan penelitian ini untuk mengetahui bagaimana persepsi pustakawan terhadap kinerja tim penilai angka kredit jabatan fungsional pustakawan di Universitas Jenderal Soedirman. Penelitian ini merupakan penelitian kuantitatif dengan metode survey. Instrumen yang digunakan adalah kuesioner skala likert untuk mendapatkan data primer dan wawancara digunakan untuk memperdalam analisis data primer. Populasi dalam penelitian ini adalah seluruh pustakawan yang mengajukan DUPAK kepada tim penilai angka kredit pustakawan Universitas Jenderal Soedirman. Analisis data dalam penelitian ini menggunakan rumus mean dan grandmean, dengan menyusun pedoman pemaknaan terhadap skor yang didapat. Variabel kinerja dalam penelitian ini dipecah menjadi 3 subvaribel yaitu hasil kerja, perilaku kerja, dan pribadi yang berkenaan dengan pekerjaan. Hasil penghitungan skor rata-rata adalah 83,6 termasuk dalam kategori baik. Berdasarkan hasil tersebut dapat diketahui persepsi pustakawan terhadap kinerja tim penilai angka kredit jabatan fungsional pustakawan Universitas Jenderal Soedirman adalah baik.

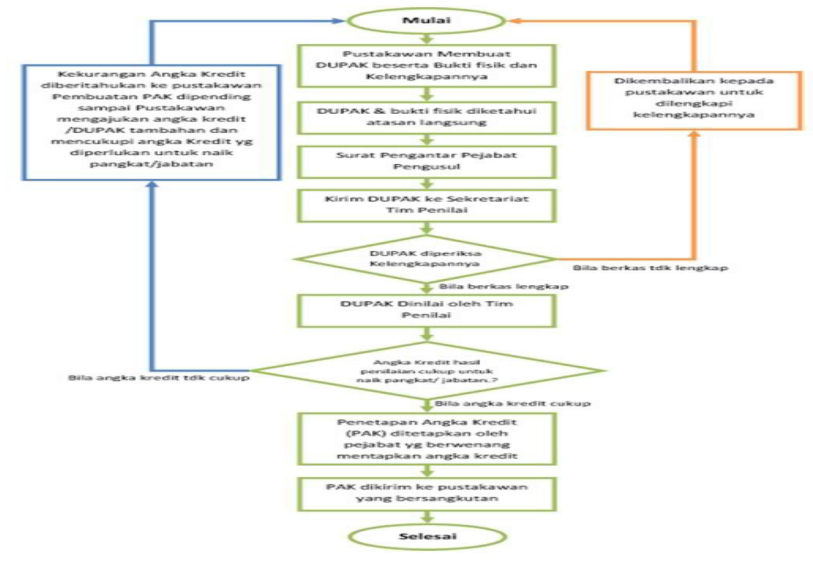

Gambar Alur Pengusulan dan Penetapan Angka

Kredit Pustakawan Sumber: http://pustakawan.

perpusnas.go.id/content/peraturan-penilaian-pak
Alur pengajuan dan penetapan angka kredit pustakawan secara tidak langsung menunjukkan faktor kelancaran jenjang karier pustakawan. Faktor tersebut adalah pustakawan yang berkewajiban mengumpulkan angka kredit dan tim penilai angka kredit berhak memutuskan hasil penilaiannya. Kemampuan tim penilai angka kredit dalam melaksanakan tugas dapat dikatakan menjadi salah satu faktor kelancaran jenjang karier pustakawan. Penulis belum menemukan kajian spesifik mengenai kinerja tim penilai angka kredit jabatan fungsional pustakawan. Penulis merasa perlu melakukan kajian ini karena tim penilai merupakan salah satu pihak yang terkait dalam kelancaran karier pustakawan. Berdasarkan pemaparan tersebut, pada kesempatan ini melakukan kajian dengan judul "Analisis Persepsi Pustakawan terhadap Kinerja Tim Penilai Angka Kredit Jabatan Fungsional Pustakawan Universitas Jenderal Soedirman". Rumusan masalah dalam penelitian ini bagaimanakah persepsi pustakawan terhadap kinerja tim penilai angka kredit jabatan fungsional pustakawan di lingkungan Universitas Jenderal Soedirman. Tujuan penelitian untuk mendeskripsikan persepsi pustakawan terhadap kinerja tim penilai angka kredit jabatan fungsional pustakawan di lingkungan Universitas Jenderal Soedirman.

\section{B. KAJIAN TEORITIS}

Persepsi adalah proses yang menyangkut masuknya pesan atau informasi ke dalam otak manusia (Slameto, 2013). Manusia mengadakan hubungan dengan lingkungannya secara terusmenerus melalui persepsi. Hubungan ini dilakukan lewat inderanya yaitu indera penglihat, pendengar, peraba, perasa dan pencium. Persepsi merupakan pengalaman tentang objek, peristiwa, atau hubungan-hubungan yang diperoleh dengan menyimpulkan informasi dan menafsirkan pesan (Sularso, Havid, \& Purwati, 2009). Secara psikologis dapat dikatakan bahwa setiap orang 
mempersepsikan stimulasi sesuai dengan karakteristik personalnya. Timbulnya persepsi karena adanya sensasi yaitu proses menangkap stimulasi atau suatu pengalaman elementer yang segera dan tidak memerlukan penguraian verbal, simbolis, atau konseptual dan terutama berhubungan dengan kegiatan indera.

Berdasarkan pengertian tersebut dapat disimpulkan persepsi merupakan proses pemaknaan terhadap stimulasi berupa pengalaman yang diterima melalui indera penglihat, pendengar, peraba, perasa dan pencium sehingga dapat menimbulkan tanggapan suatu penafsiran. Persepsi pustakawan dalam kajian ini adalah suatu pemaknaan pustakawan terhadap kinerja tim penilai angka kredit jabatan fungsional pustakawan setelah melalui proses penginderaan terhadap pengalaman pengajuan dan penetapan angka kredit yang diterima sehingga menimbulkan tanggapan serta bentuk penafsiran pengalaman.

Konsep kinerja merupakan singkatan dari kinetika energy kerja yang padanannya dalam bahasa Inggris adalah performance. Kinerja adalah keluaran yang dihasilkan oleh fungsi-fungsi atau indikator-indikator suatu pekerjaan atau suatu profesi dalam waktu tertentu (Wirawan, 2009). Secara umum Wirawan menyebutkan indikator kinerja dapat dikelompokkan menjadi tiga jenis yaitu. (1) Hasil kerja. Hasil kerja adalah keluaran kerja dalam bentuk barang dan jasa yang dapat dihitung dan diukir kuantitas dan kualitasnya. (2) Perilaku kerja. Perilaku kerja adalah perilaku pekerja yang ada hubungannya dengan pekerjaan. Perilaku kerja diperlukan karena merupakan persyaratan dalam melaksanakan pekerjaan. Dengan berperilaku kerja tertentu, pekerja/ karyawan dapat melaksanakan pekerjaan dengan baik dan menghasilkan kinerja yang diharapkan organisasi. (3) Sifat pribadi yang ada hubungannya dengan pekerjaan adalah sifat pribadi karyawan yang diperlukan dalam melaksanakan pekerjaannya.
Pengertian tim penilai berkaitan dengan pengertian angka kredit. Angka kredit adalah satuan nilai dari setiap butir kegiatan atau akumulasi butirbutir kegiatan yang harus dicapai oleh pustakawan dalam rangka pembinaan karier pustakawan (Peraturan Kepala Perpusnas RI No. 11 Tahun 2015 tentang Petunjuk Teknis Jabatan Fungsional Pustakawan, 2015). Lasa menyampaikan angka kredit adalah suatu angka yang diberikan kepada seorang pejabat fungsional berdasarkan atas prestasi yang telah dicapainya dalam mengerjakan kegiatan kepustakawaan, butir kegiatan tersebut merupakan salah satu syarat pengangkatan dan/ atau kenaikan jabatan/ pangkat/ golongan dalam jabatan fungsional tertentu (HS, 2014). Berdasarkan pengertian tersebut dapat dipahami angka kredit merupakan sekumpulan hasil pelaksanaan kegiatan kepustakawanan (prestasi kerja/ aktualisasi kompetensi) yang diakui dan ditetapkan untuk pengangkatan pertama kali sebagai pejabat fungsional, kenaikan jabatan, pangkat dan golongan fungsional.

Pemaparan tersebut menjadi dasar pengertian kinerja tim penilai angka kredit jabatan fungsional pustakawan yaitu hasil kerja yang ditunjukkan dalam proses penilaian prestasi berupa pengumpulan angka kredit pustakawan. Indikator kinerja tim penilai angka kredit jabatan fungsional pustakawan adalah (1) hasil kerja, berupa kualitas hasil penghitungan angka kredit pustakawan dan waktu penghitungan angka kredit; (2) Perilaku kerja, berupa kemampuan kerja sama, integritas, membangun kepercayaan, pengembangan diri, dan profesionalisme; (3) Sifat pribadi yang ada hubungannya dengan pekerjaan yaitu keterbukaan, jujur, dan tanggungjawab.

Etty Andriaty dan Hendrawaty melakukan pengkajian dengan judul Kajian Penilaian Angka Kredit Pustakawan Lingkup Kementerian Pertanian padatahun2012.Tujuan pengkajian(1)mengevaluasi kenerja pustakawan lingkup kementrian Pertanian 
melaui penilaian hasil kegiatan, (2) mengetahui kesenjangan penilaian, dan (3) mengidentifikasi masalah dalam penilaian angka kredit pustakawan. Hasil pengkajian menunjukkan bahwa jumlah angka kredit yang diajukan pustakawan berbeda dengan hasil penilaian Tim Penilai. Masalah dalam penilaian angka kredit adalah ketidaklengkapan dokumen yang akan dinilai dan belum adanya kesamaan persepsi mengenai cara penghitungan angka kredit untuk tiap butir kegiatan antara Tim Penilai dan pustakawan. Pengkajian ini belum terlihat kinerja Tim Penilai. Demikian juga kajian yang dilakukan Lasa (2014) menyampaikan beberapa hal yang menganggu proses kenaikan jabatan, meliputi: (1) pengisian DUPAK kadang tidak realistik karena kegiatan terlalu banyak dan dalam waktu/ hari yang sama melakukan dua kegiatan yang menurut logika tidak mungkin dilakukan; (2) pemborosan administrasi; (3) kegiatan pustakawan masih terfokus pada kegiatan ketrampilan; (4) satu kegiatan dinilai dua kegiatan atau lebih; (5) sangat minim kegiatan profesional; (6) data pendukung kadang kadaluarsa bahkan tidak relevan. Peneliti mendapatkan keterbatasan dalam menemukan kajian yang khusus membahas kinerja Tim Penilai.

Beberapa kajian menunjukkan "keterbatasan" dari sisi pustakawan dalam proses pengajuan dan penyusunan DUPAK dan membahas mengenai temuan kendala yang dihadapi pustakawan dalam pengajuan angka kredit. Berdasarkan kjian terdahulu, terlihat perbedaan dalam kajian ini berusaha menampilkan kinerja tim penilai angka kredit dan bagaimana persepsi pustakawan terhadap kinerja terbut.

\section{METODE PENELITIAN}

Penelitian ini merupakan penelitian kuantitatif dengan metode survei. Subyek penelitian adalah seluruh pustakawan yang pernah mengajukan DUPAK kepada tim penilai angka kredit jabatan fungsional pustakawan di lingkungan Universitas
Jenderal Soedirman. Obyek penelitian ini adalah kinerja tim penilai angka kredit jabatan fungsional pustakawan Universitas Jenderal Soedirman. Populasi dalam penelitian adalah seluruh pustakawan yang mengajukan DUPAK kepada tim penilai angka kredit jabatan fungsional pustakawan Universitas Jenderal Soedirman yaitu pustakawan pada Universitas Jenderal Soedirman berjumlah 20 orang dan pustakawan pada IAIN Purwokerto berjumlah 3 orang. Total populasi dalam penelitian adalah 23 orang. Penentuan sampel merujuk pada sampling jenuh yaitu penentuan sampel apabila semua anggota populasi digunakan sebagai sampel, karena jumlah populasi relatif kecil dan ingin membuat generalisasi dengan kesalahan yang sangat kecil (Sugiyono, 2014a).

Instrumen penelitian berupa kuesioner tertutup disusun berdasarkan indikator kinerja yang disampaikan Wirawan dan dikembangkan sesuai kajian teori yang dilakukan peneliti (Wirawan, 2009). Jumlah pernyataan dalam kuesioner adalah 23 butir dengan skala Likert. Uji validitas dalam penelitian ini menggunakan rumus korelasi pearson product moment. Butir pernyataan dinyatakan valid apabila korelasi tiap faktor tersebut positif dan besarnya 0,3 ke atas (Sugiyono, 2014b). Hasil uji validitas menunjukkan korelasi tiap butir pernyataan di atas 0,3 dengan demikian butir pernyataa dalam kuesioner dinyatakan valid. Uji reliabilitas merupakan kesesuaian alat ukur dengan yang diukur sehingga alat ukur dapat dipercaya atau dapat diandalkan. Uji reliabilitas dapat dilihat pada nilai Alpha, jika nilai Alpha Cronbach > 0,60 maka reliabel. Hasil uji reliabilitas bernilai lebih besar dari 0,600, dengan demikian butir kuesioner dinyatakan reliabel. Analisis data dalam penelitian ini menggunakan rumus mean dan grandmean. Selanjutnya, untuk memberikan pemaknaan terhadap skor pada persepsi pustakawan terhadap kinerja Tim Penilai angka kredit jabatan fungsional pustakawan Universitas Jenderal Soedirman, 
penulis menyusun pedoman penafsiran menurut pedoman yang dikemukakan Sukiman (Sukisman, 2012).

\section{HASIL DAN PEMBAHASAN}

Peneliti telah menyebarkan 23 kuesioner untuk mengumpulkan data primer dalam penelitian ini. Kuesioner tersebut meliputi 23 butir pernyataan dan 3 sub variabel. Data primer yang telah berhasil dikumpulkan kemudian dideskripsikan dengan melakukan pengukuran nilai rata-rata hitung pada setiap aspek untuk memberikan gambaran data yang diperoleh. Hasilnya disajikan dalam bentuk tabel. Selanjutnya, peneliti memberikan pemaknaan terhadap skor pada kinerja tim penilai angka kredit jabatan fungsional pustakawan. Berdasarkan hasil analisis data, peneliti mendapatkan suatu kesimpulan yang dapat dimanfaatkan (generalisasi) untuk populasi. Berikut ini pemaparan hasil penelitian.

Tim penilai angka kredit jabatan fungsional pustakawan Universitas Jenderal Soedirman melaksanakan tugas berdasarkan Keputusan Rektor Universitas Jenderal Soedirman No.: Kept. 351/UN23/KP.03.00/2017 tentang Pengangkatan Tim Penilai Angka Kredit dan Sekretariat Panitia Penilai Jabatan Pustakawan Universitas Jenderal Soedirman. Adapun tugas tim penilai adalah pertama, membantu pejabat yang berwenang menetapkan angka kredit dalam melakukan penilaian terhadap usul penetapan angka kredit pustakawan yang menjadi kewenangannya. Tugas kedua adalah melaksanakan tugas lain yang diberikan oleh rektor yang berhubungan dengan penilaian angka kredit pustakawan perguruan tinggi. Selain menilai angka kredit pustakawan lingkup intern, tim penilai angka kredit jabatan fungsional pustakawan Universitas Jenderal Soedirman Pustakawan membantu melakukan penilaian terhadap angka kredit pustakawan IAIN
Purwokerto karena perguruan tinggi tersebut belum memiliki tim penilai.

Responden dalam penelitian ini adalah seluruh pustakawan yang mengajukan DUPAK kepada tim penilai angka kredit jabatan fungsional pustakawan di lingkungan Universitas Jenderal Soedirman kecuali pustakawan menjabat sebagai tim penilai. Hal ini dilakukan untuk menghindari bias dalam penelitian. Berdasarkan kriteria tersebut didapat pustakawan pada Universitas Jenderal Soedirman berjumlah 20 orang dan pustakawan pada IAIN Purwokerto berjumlah 3 orang, sehingga jumlah responden adalah 23 pustakawan. Responden diidentifikasikan menurut jenis kelamin dan pengalaman mengajukan DUPAK. Adapun identifikasi responden sebagai berikut.

Tabel 1. Deskripsi Responden

\begin{tabular}{|c|c|c|c|c|}
\hline \multirow{2}{*}{$\begin{array}{c}\text { Pengalaman } \\
\text { mengajukan } \\
\text { DUPAK }\end{array}$} & \multicolumn{2}{|c|}{ Jenis Kelamin } & \multirow{2}{*}{ Frekuensi } & \multirow{2}{*}{ Persentase } \\
\hline & Laki-Laki & Perempuan & & \\
\hline 2 kali & 2 & 4 & 6 & $26,09 \%$ \\
\hline 3 kali & 6 & 3 & 9 & $39,13 \%$ \\
\hline 4 kali & 1 & 2 & 3 & $13,04 \%$ \\
\hline 5 kali & - & 1 & 1 & $4,35 \%$ \\
\hline 6 kali & - & - & - & - \\
\hline$\geq 7$ kali & - & 4 & 4 & $17,39 \%$ \\
\hline Total & 9 & 14 & 23 & $100 \%$ \\
\hline
\end{tabular}

Sumber: Data primer diolah, 2017

Berdasarkan tabel di atas, dapat diketahui bahwa deskripsi responden berdasarkan jenis kelamin menunjukkan bahwa responden perempuan dalam penelitian ini sebanyak 14 pustakawan atau $61 \%$, sedangkan laki-laki sebanyak 9 pustakawan atau 39\%. Dengan demikian dapat disimpulkan bahwa responden perempuan lebih banyak dibandingkan dengan responden laki-laki. Deskripsi responden berdasarkan pengalaman mengajukan DUPAK menunjukkan bahwa sebagian besar responden pernah mengajukan DUPAK sebanyak 3 kali atau 39,13\%. 
Hasil sebaran kuesioner persepsi pustakawan terhadap hasil kerja tim penilai melalui 2 indikator dengan jumlah item sebanyak 5 butir pernyataan, terlihat pada tabel berikut.

Tabel 2. Deskripsi Hasil Kerja Tim Penilai

\begin{tabular}{|c|c|c|c|c|c|c|c|c|c|}
\hline \multirow{2}{*}{ No } & \multirow{2}{*}{ Pernyataan } & \multicolumn{5}{|c|}{ Skor } & \multirow{2}{*}{ Total } & \multirow{2}{*}{ Mean } & \multirow{2}{*}{$\begin{array}{l}\text { Grand } \\
\text { Mean }\end{array}$} \\
\hline & & 1 & 2 & 3 & 4 & 5 & & & \\
\hline 1. & $\begin{array}{l}\text { Penetapan Angka Kredit (PAK) } \\
\text { dapat saya terima dalam } \\
\text { waktu kurang dari dua bulan } \\
\text { setelah penyerahan Daftar } \\
\text { Usulan Penetapan Angka Kredit } \\
\text { (DUPAK) kepada Tim Penilai }\end{array}$ & 2 & 2 & 3 & 12 & 4 & 23 & 3.61 & \multirow{3}{*}{3.57} \\
\hline 2. & $\begin{array}{l}\text { Tim penilai mampu menyelesaikan } \\
\text { penghitungan angka kredit } \\
\text { dalam waktu sesuai harapan } \\
\text { pengusul (pustakawan). }\end{array}$ & 0 & 3 & 5 & 13 & 2 & 23 & 3.61 & \\
\hline 3. & $\begin{array}{l}\text { Penetapan Angka Kredit (PAK) } \\
\text { dapat diterima tepat waktu } \\
\text { sehingga memperlancar } \\
\text { kenaikan jabatan ataupun } \\
\text { kenaikan pangkat. }\end{array}$ & 2 & 3 & 4 & 10 & 4 & 23 & 3.48 & \\
\hline 4. & $\begin{array}{l}\text { Hasil penghitungan angka } \\
\text { kredit yang diusulkan konsisten } \\
\text { dengan tingkat kesalahan } 0 \% \text {. }\end{array}$ & 1 & 9 & 7 & 6 & 0 & 23 & 2.78 & \multirow[t]{2}{*}{3.30} \\
\hline 5. & $\begin{array}{l}\text { Tim penilai mampu menampilkan } \\
\text { hasil kerja yang teliti. }\end{array}$ & 0 & 0 & 6 & 15 & 2 & 23 & 3.83 & \\
\hline
\end{tabular}

Sumber: Data primer diolah, 2017

Berdasarkan tabel terlihat tanggapan responden terhadap hasil kerja tim penilai. Indikator waktu penyelesaian penghitungan angka kredit dan Penetapan Angka Kredit mendapat nilai rata-rata lebih tinggi dibandingkan dengan kualitas hasil penghitungan angka kredit pustakawan. Butir pernyataan hasil penghitungan angka kredit yang diusulkan konsisten dengan tingkat kesalahan 0\% mendapat skor paling rendah yakni 2.78 . Selanjutnya, peneliti memberikan pemaknaan terhadap skor pada hasil kerja tim penilai sesuai pedoman penafsiran yang telah disusun menggunakan 2 indikator dengan jumlah item 5 butir pernyataan. Deskripsi hasil kerja tim penilai yang dijabarkan dalam dua indikator mendapat skor rata-rata 16. Berdasarkan pedoman penafsiran rata-rata 16 berada pada rentang 13 - 16 termasuk dalam kategori cukup. Dengan demikian dapat dipahami persepsi pustakawan terhadap hasil kerja tim penilai termasuk dalam kategori cukup.
Hasil sebaran kuesioner persepsi pustakawan terhadap perilaku kerja melalui 5 indikator dengan jumlah item sebanyak 10 butir pernyataan terlihat dalam tabel berikut.

Tabel 3. Deskripsi Perilaku Kerja Tim Penilai

\begin{tabular}{|c|c|c|c|c|c|c|c|c|c|}
\hline \multirow{2}{*}{ No } & \multirow{2}{*}{ Pernyataan } & \multicolumn{5}{|c|}{ Skor } & \multirow{2}{*}{ Total } & \multirow{2}{*}{ Mean } & \multirow{2}{*}{$\begin{array}{l}\text { Grand } \\
\text { mean }\end{array}$} \\
\hline & & 1 & 2 & 3 & 4 & 5 & & & \\
\hline 6. & $\begin{array}{l}\text { Anggota tim penilai mampu } \\
\text { membina hubungan } \\
\text { kerja sehingga terwujud } \\
\text { kerjasama yang solid. }\end{array}$ & 0 & 1 & 10 & 8 & 4 & 23 & 3.65 & \multirow{2}{*}{3.72} \\
\hline 7. & $\begin{array}{l}\text { Anggota mampu bekerja } \\
\text { efektif dalam tim sehingga } \\
\text { memperlancar pelaksanaan } \\
\text { tugas bersama. }\end{array}$ & 0 & 0 & 9 & 10 & 4 & 23 & 3.78 & \\
\hline 8. & $\begin{array}{l}\text { Tim penilai bertanggungjawab } \\
\text { atas setiap tindakan yang diambil. }\end{array}$ & 0 & 0 & 4 & 13 & 6 & 23 & 4.09 & \multirow[b]{2}{*}{4.02} \\
\hline 9. & $\begin{array}{l}\text { Tim penilai melakukan } \\
\text { penghitungan angka kredit sesuai } \\
\text { standar atau juknis yang berlaku. }\end{array}$ & 0 & 0 & 5 & 14 & 4 & 23 & 3.96 & \\
\hline 10. & $\begin{array}{l}\text { Tim penilai dapat dipercaya } \\
\text { dalam melaksanakan tugas. }\end{array}$ & 0 & 0 & 4 & 13 & 6 & 23 & 4.09 & \multirow[b]{2}{*}{3.91} \\
\hline 11. & $\begin{array}{l}\text { Tim penilai terbuka terhadap } \\
\text { masukan/ ide sehingga terjadi } \\
\text { interaksi sesuai harapan } \\
\text { pengusul (pustakawan). }\end{array}$ & 0 & 1 & 8 & 10 & 4 & 23 & 3.74 & \\
\hline 12. & $\begin{array}{l}\text { Tim penilai berperilaku } \\
\text { jujur dalam melaksanakan } \\
\text { tugas yang diberikan sesuai } \\
\text { juknis yang berlaku. }\end{array}$ & 0 & 1 & 5 & 12 & 5 & 23 & 3.91 & \multirow[t]{2}{*}{3.85} \\
\hline 13. & $\begin{array}{l}\text { Tim penilai menjadi panutan } \\
\text { bagi pustakawan lainnya } \\
\text { dalam berperilaku kerja. }\end{array}$ & 0 & 1 & 8 & 9 & 5 & 23 & 3.78 & \\
\hline 14. & $\begin{array}{l}\text { Anggota tim penilai secara } \\
\text { konsisten mengembangkan } \\
\text { diri untuk mendukung } \\
\text { pelaksanaan tugasnya. }\end{array}$ & 0 & 0 & 7 & 10 & 6 & 23 & 3.96 & \multirow[t]{2}{*}{3.89} \\
\hline 15. & $\begin{array}{l}\text { Tim penilai menjadi panutan } \\
\text { bagi pustakawan lainnya } \\
\text { dalam pengembangan diri. }\end{array}$ & 0 & 0 & 9 & 9 & 5 & 23 & 3.83 & \\
\hline
\end{tabular}

Sumber: Data primer diolah, 2017

Berdasarkan tabel terlihat tanggapan responden terhadap perilaku kerja tim penilai. Indikator perilaku professional tim penilai mendapat nilai rata-rata paling tinggi yakni 4.02. Butir pernyataan anggota tim penilai mampu membina hubungan kerja sehingga terwujud kerjasama yang solid mendapat skor paling rendah yakni 3.65. Selanjutnya, peneliti memberikan pemaknaan terhadap skor pada perilaku kerja tim penilai sesuai pedoman penafsiran yang telah disusun menggunakan 5 indikator dengan jumlah item 10 butir pernyataan mendapat skor rata-rata 
36. Berdasarkan pedoman penafsiran rata-rata 36 berada pada rentang 34 - 41 termasuk dalam kategori baik. Dengan demikian dapat dipahami peprsepsi pustakawan terhadap perilaku kerja tim penilai termasuk dalam kategori baik.

Hasil sebaran kuesioner persepsi pustakawan terhadap pribadi yang ada hubungannya dengan pelaksanaan tugas tim penilai diperoleh melalui 5 indikator dengan jumlah item sebanyak 8 butir pernyataan terlihat pada tabel berikut.

Tabel 4. Deskripsi pribadi yang berhubungan dengan Pelaksanaan Tugas

\begin{tabular}{|c|c|c|c|c|c|c|c|c|c|}
\hline \multirow{2}{*}{ No } & \multirow{2}{*}{ Pernyataan } & \multicolumn{5}{|c|}{ Skor } & \multirow{2}{*}{ Total } & \multirow{2}{*}{ Mean } & \multirow{2}{*}{$\begin{array}{l}\text { Grand } \\
\text { mean }\end{array}$} \\
\hline & & 1 & 2 & 3 & 4 & 5 & & & \\
\hline 16. & $\begin{array}{l}\text { Tim penilai mampu menguasai tata } \\
\text { cara penghitungan angka kredit. }\end{array}$ & 0 & 0 & 4 & 16 & 3 & 23 & 3.96 & 3.96 \\
\hline 17. & $\begin{array}{l}\text { Tim penilai menjadi panutan dalam } \\
\text { semangat kerja bagi pustakawan } \\
\text { lainnya. }\end{array}$ & 0 & 0 & 7 & 9 & 7 & 23 & 4.00 & 4.00 \\
\hline 18. & $\begin{array}{l}\text { Tim penilai tidak pernah } \\
\text { menyalahgunakan wewenangnya. }\end{array}$ & 0 & 0 & 4 & 15 & 4 & 23 & 4.00 & \\
\hline 19. & $\begin{array}{l}\text { Tim penilai melaksanakan tugas } \\
\text { dengan ikhlas. }\end{array}$ & 0 & 0 & 6 & 12 & 5 & 23 & 3.96 & 3.8 \\
\hline 20. & $\begin{array}{l}\text { Tim penilai berani memikul risiko } \\
\text { dari keputusan yang diambil. }\end{array}$ & 0 & 0 & 6 & 11 & 6 & 23 & 4.00 & \\
\hline 21. & $\begin{array}{l}\text { Tim penilai mengutamakan } \\
\text { kepentingan dinas daripada } \\
\text { kepentingan diri sendiri. }\end{array}$ & 0 & 0 & 8 & 11 & 4 & 23 & 3.83 & 3.91 \\
\hline 22. & $\begin{array}{l}\text { Tim penilai melakukan bimbingan } \\
\text { bagi pengusul dengan kesabaran. }\end{array}$ & 0 & 2 & 6 & 11 & 4 & 23 & 3.74 & \\
\hline 23. & $\begin{array}{l}\text { Tim penilai } \quad \text { mampu } \\
\text { memperlakukan } \quad \text { pengusul } \\
\text { (pustakawan) secara sama/ tidak } \\
\text { pilih kasih. }\end{array}$ & 0 & 2 & 6 & 9 & 6 & 23 & 3.83 & 3.78 \\
\hline
\end{tabular}

Sumber: Data primer diolah, 2017

Berdasarkan tabel terlihat tanggapan responden terhadap pribadi yang ada hubungannya dengan pelaksanaan tugas tim penilai. Indikator semangat tim penilai mendapat nilai rata-rata paling tinggi yakni 4.00. Butir pernyataan Tim penilai melakukan bimbingan bagi pengusul dengan kesabaran pada indikator inisiatif. mendapat skor paling rendah yakni 3.74. Selanjutnya, peneliti memberikan pemaknaan terhadap skor pada pribadiyang ada hubungannya dengan pelaksanaan tugas tim penilai sesuai pedoman penafsiran yang telah disusun menggunakan 5 indikator dengan jumlah item 8 butir pernyataan. Deskripsi pribadi yang ada hubungannya dengan pelaksanaan tugas tim penilai yang dijabarkan dalam lima indikator mendapat skor rata-rata 28. Berdasarkan pedoman penafsiran rata-rata 28 berada pada rentang 26 - 31 termasuk dalam kategori baik.

Deskripsi persepsi pustakawan terhadap kinerja tim penilai angka kredit jabatan fungsional pustakawan dapat dilihat berdasarkan hasil sebaran kuesioner dengan jumlah 3 sub variabel dengan 12 indikator dengan jumlah item sebanyak 23 butir pernyataan. Peneliti memberikan pemaknaan terhadap skor pada kinerja tim penilai angka kredit jabatan fungsional pustakawan sesuai pedoman penafsiran yang telah disusun didapat pedoman penafsiran sebagai berikut.

Tabel 5. Pedoman Pemaknaan Deskripsi persepsi pustakawan terhadap kinerja tim penilai angka kredit jabatan fungsional pustakawan

\begin{tabular}{|cccccc|}
\hline Kategori & $\begin{array}{c}\text { Nilai } \\
\text { Interval }\end{array}$ & $\begin{array}{c}\text { Titik } \\
\text { Tengah }\end{array}$ & Frekuensi & Jumlah & Mean \\
\hline Sangat Baik & $96.6-115$ & 105.8 & 100 & 10580 & \\
\hline Baik & $78.2-96.5$ & 87.35 & 258 & 22536.3 & \\
\cline { 1 - 5 } Cukup & $59.4-78.1$ & 68.75 & 141 & 9693.75 & \\
\hline Buruk & $41.4-59.3$ & 50.35 & 25 & 1258.75 \\
\hline Sangat Buruk & $23-41.3$ & 32.15 & 5 & 160.75 \\
\hline
\end{tabular}

Sumber: Data primer diolah 2017

Deskripsi persepsi pustakawan terhadap kinerja tim penilai angka kredit jabatan fungsional pustakawan yang dijabarkan dalam dua belas indikator mendapat skor rata-rata 83.61. Berdasarkan pedoman penafsiran rata-rata 83.61 berada pada rentang 78.2 - 96.5 termasuk dalam kategori baik. Dengan demikian dapat dipahami persepsi pustakawan terhadap kinerja tim penilai angka kredit jabatan fungsional pustakawan termasuk dalam kategori baik.

Berdasarkan hasil temuan tersebut terlihat kenaikan jenjang karir pustakawan bergantung pada kompetensi diri dan usaha yang dilakukan. Meskipun demikian, ada beberapa pihak yang 
terkait dalam kelancaran karir pustakawan. Salah satunya adalah tim penilai angka kredit. Dapat dipahami, kinerja tim penilai berperan terhadap kelancaran karir pustakawan. Hal ini didukung dengan pernyataan Sutarsyah bahwa kiprah tim penilai sangat berarti untuk mendukung dan meningkatkan kinerja pustakawan dalam pengajuan angka kredit (Sutarsyah, 2011). Pernyataan tersebut diperkuat oleh Harjo menyampaikan bahwa tim penilai merupakan unsur yang mempunyai peranan penting dalam pengembangan karir pustakawan, karena hal tersebut tim penilai harus menjamin objektivitas dalam kelancaran penilaian angka kredit. Tim penilai hendaknya memiliki kompetensi dalam melakukan penilaian,objektivitas dan memahami kegiatan kepustakawanan (Harjo, 2014).

Temuan berdasarkan analisis deskripsi terhadap kuesioner menunjukkan hasil kerja tim penilai mendapat skor terendah dibandingkan dengan perilaku kerja tim penilai dan sifat pribadi yang ada hubungannya dengan pelaksanaan tugas tim penilai. Persepsi pustakawan terhadap hasil kerja tim penilai masuk dalam kategori cukup. Hal ini ditunjukkan dengan skor rata-rata 16 termasuk dalam rentang 13 - 16. Subvariabel hasil kerja kualitas penghitungan angka kredit mendapat skor terendah yakni 2,78. Hal ini membuktikan pernyataan Saleh (2004) bahwa salah satu masalah yang dihadapi tim penilai adalah kualitas tim penilai itu sendiri. Saleh menyatakan "jika pustakawan dituntut untuk mengajukan DUPAK dengan baik dan berkualitas (khususnya dari kegiatan kajian dan pengembangan profesi), maka anggota tim penilai harus dipilih dari pustakawan yang mempunyai kualitas dan integritas yang tinggi". Hasil wawancara peneliti dengan sekretaris tim penilai angka kredit mendukung pernyataan Saleh, bahwa terdapat anggota tim penilai yang belum memiliki sertifikat diklat tim penilai angka kredit yang diselenggarakan oleh Perpustakaan Nasional Republik Indonesia. Hal ini dimungkinkan mempengaruhi kualitas hasil penilaian menjadi lebih rendah dibanding indikator yang lain. Kualitas penghitungan angka kredit hendaknya dapat diperbaiki dari sisi intern tim penilai yakni dengan melakukan evaluasi terhadap berita acara yang dibuat setelah penghitungan angka kredit, memanfaatkan peluang untuk mengikuti diklat, serta terbuka melakukan sharing dengan tim penilai unit lain. Dari sisi ekstern tim penilai yakni adanya dukungan tim penilai pusat dan perlu adanya uji sertifikasi ataupun uji kompetensi khusus bagi tim penilai. Hal ini perlu dilakukan karena pustakawan sebagai pengusul angka kredit disyaratkan melakukan uji kompetensi ataupun sertifikasi sebagai syarat kenaikan jabatan fungsional apalagi Tim Penilainya. Hal ini diharapkan dapat menjamin kehandalan hasil kerja tim penilai.

Persepsi pustakawan terhadap perilaku kerja tim penilai angka kredit jabatan fungsional pustakawan Universitas Jenderal Soedirman mendapat skor rata-rata 36 termasuk dalam kategori baik. Perilaku kerja tim penilai dapat diperbaiki melalui peningkatan kemampuan kerjasama dalam tim, profesionalisme, membangun kepercayaan, integritas, pengembangan diri. Ada baiknya Perpusnas RI membentuk "dewan kehormatan" yang bertugas mengontrol perilaku kerja tim penilai. Persepsi pustakawan terhadap sifat pribadi yang ada hubungannya dengan pelaksanaan tugas tim penilai mendapat skor 28 berada pada rentang 26 - 31 termasuk dalam kategori baik. Indikator inisatif tim penilai mendapat skor terendah yakni 3,78 . Tim penilai perlu melakukan suatu terobosan untuk melakukan kegiatan di luar tugas pokoknya, selain melakukan supervise dan koordinasi, juga melakukan pendataan, pemantauan pengkajian, bimbingan, pembinaan mengkoordinir dan mengevaluasi para pustakawan dan calon pustakawan dilingkup bidang tugas penilai (Sutarsyah, 2011).

Hasil analisis deskripsi persepsi pustakawan terhadap kinerja tim penilai angka kredit jabatan 
fungsional pustakawan meliputi tiga indikator yakni hasil kerja, perilaku kerja, dan pribadi yang ada hubungannya dengan pelaksanaan tugas adalah termasuk kategori baik. Hal ini ditunjukkan skor rata-rata adalah 83,61 termasuk dalam rentang $78,2-96,5$. Berdasarkan wawancara peneliti dengan ketua tim penilai, diketahui bahwa tim penilai sudah melakukan beberapa upaya dalam memperlancar pelaksanaan tugasnya. Upaya tersebut berupa melakukan diklat penyusunan DUPAK ditujukan bagi semua pustakawan dengan mengundang tim penilai pusat sebagai pemateri. Selanjutnya tim penilai berupaya segera memproses penilain terhadap angka kredit yang diusulkan pustakawan agar PAK dapat selesai tepat waktu sehingga dapat memperlancar jenjang karier pustakawan. Tim penilai juga segera menginformasikan kepada pustakawan pengusul apabila didapati kekurangan kelengakapan bukti kegiatan kepustakawanan.

Berdasarkan hasil tersebut, tim penilai perlu berperan lebih aktif dalam pengembangan kompetensi pustakawan dan diharapkan memberikan dampak positif dalam peningkatan jenjang karir. Peran aktif tim penilai dapat dilakukan dengan membuka "klinik" bagi pustakawan. Klinik dimaksudkan untuk memberikan konsultasi dan juga pendampingan. Konsultasi diharapkan dapat memperlancar komunikasi antara pustakawan dan tim penilai sehingga lebih mudah menyamakan persepsi dalam memahami acuan dan pedoman pelaksanaan jabatan fungsional pustakawan. Hal ini untuk meminimalisir kesalahfahaman dan terkadang mengecilkan hati pustakawan manakala butir kegiatan kepustakawanan yang dilakukan tidak dapat dinilai karena bukti kegiatan tidak sesuai.

Tim penilai hendaknya melakukan pendampingan kepada pustakawan di lingkungan yang menjadi tanggungjawab penilaiannya. Pendampingan dapat dilakukan bagi semua pustakawan terutama bagi pustakawan yang sudah saatnya "naik jabatan" ataupun pustakawan yang mengalami kesulitan dalam pengajuan angka kredit. Karena hal tersebut, tim penilai harus memiliki data lengkap dan selalu diperbaharui sesuai kenaikan jabatan pustakawan yang berada dalam lingkup tugasnya. Data terbaru tersebut disusun sedemikian rupa hingga memudahkan tim penilai melakukan pemetaan untuk pendampingan. Tim penilai dapat memberikan motivasi kepada pustakawan untuk melakukan butir kegiatan yang tidak hanya bernilai tinggi tetapi juga menghasilkan produk keilmuan yang memberikan manfaat nyata bagi lingkungan masyarakat secara luas. Tim penilai perlu melakukan evaluasi setiap kali melakukan tugas penilaian. Hasil evaluasi berupa temuan dalam tata cara penyusunan DUPAK, butir kegiatan, satuan hasil kegiatan, dan juga bukti kegiatan yang tidak sesuai dengan pedoman pelaksanan jabatan fungsional pustakawan perlu dicatat dan segera disampaikan pada pustakawan yang bersangkutan dan ditindaklanjuti dengan pendampingan mengenai penyusunan DUPAK agar pustakawan dapat mengembangkan karir secara optimal.

\section{E. PENUTUP}

Penelitian ini dapat disimpulkan sebagai berikut.

1. Pustakawan mempersepsikan tim penilai angka kredit jabatan fungsional pustakawan Universitas Jenderal Soedirman melakukan kinerjanya dengan baik. Hal ini ditunjukkan dengan penghitungan skor rata-rata adalah 83,61 termasuk dalam rentang 78,2 - 96,5.

2. Pustakawan mempersepsikan hasil kerja tim penilai angka kredit jabatan fungsional pustakawan Universitas Jenderal Soedirman cukup. Hal ini ditunjukkan dengan penghitungan skor rata-rata adalah dengan skor rata-rata 16 termasuk dalam rentang 13 $-16$. 
3. Persepsi pustakawan terhadap perilaku kerja tim penilai angka kredit jabatan fungsional pustakawan Universitas Jenderal Soedirman adalah baik. Hal ini ditunjukkan dengan penghitungan skor rata-rata adalah 36 berada pada rentang 34 - 41 termasuk dalam kategori baik.

4. Persepsi pustakawan terhadap pribadi yang ada hubungannya dengan pelaksanaan tugas tim penilai angka kredit jabatan fungsional pustakawan Universitas Jenderal Soedirman adalah baik. Hal ini ditunjukkan dengan penghitungan skor rata-rata 28 berada pada rentang 26 - 31 termasuk dalam kategori baik.

\section{DAFTAR PUSTAKA}

Harjo. (2014). Praktik Penilaian Angka Kredit: Bahan Ajar Diklat Tim Penilai Jabatan Fungsional Pustakawan. Jakarta: Perpustakaan Nasional Republik Indonesia.

HS, L. (2014). Dibalik Angka Kredit dan Pengumpulannya. WIPA, 18, 2-19.

Perpustakaan Nasional Republik Indonesia (2015). Peraturan Kepala Perpustakaan Nasional Republik Indonesia Nomor 11 Tahun 2015 Tentang Petunjuk Teknis Jabatan Fungsional Pustakawan dan Angka Kreditnya.

......... Surat Edaran Nomor 40361/1/KPG.09.00/ XI.2015 tentang Jabatan Fungsional Pustakawan

Saleh, A. R. (2014). Catatan Penilaian Angka Kredit Pustakawan: Kajian Berdasarkan Pengalaman Menilai. Media Pustakawan, 16(1), 10-12.

Slameto. (2013). Belajar dan Faktor-Faktor yang Mempengaruhi. Jakarta: Rieneka Cipta.

Sugiyono. (2014a). Metode Penelitian Kombinasi Mixed Methods. Bandung: Alfa Beta.

Sugiyono. (2014b). Metode Penelitian Manajemen: Pendekatan Kuatitatif, Kualitatif, Kombinasi (Mix Methods), Penelitian Tindakan (Action
Research), Penelitian Evaluasi. Bandung: Alfa Beta.

Sukisman. (2012). Pengembangan Sistem Evaluasi. Yogyakarta: Insan Madani.

Sularso, Havid, \& Purwati, A. S. (2009). Mahasiswa Pendidikan Pofesi Akuntan (Ppak) dan Mahasiswa Pasca Sarjana terhadap Due Audit Care Akuntan Publik. Purwokerto.

Sutarsyah. (2011). Kiprah Tim Penilai Pustakawan dalam Memotivasi Pustakawan Mengajukan Angka Kredit. Jurnal Pustakawan Indonesia, $11(2), 31-33$.

Universitas Jenderal Soedirman (2017). Surat Keputusan Rektor Universitas jenderal Soedirman No.: Kept. 351/UN23/KP.03.00/2017 tentang Pengangkatan Tim Penilai Angka Kredit dan Sekretariat Panitia Penilai Jabatan Pustakawan Universitas Jenderal Soedirman. Purwokerto: Universitas jenderal Soedirman. Wirawan. (2009). Evaluasi Kinerja Sumber Daya Manusia: Teori, Aplikasi, dan Penelitian. Jakarta: Salemba Empat. 